\title{
SOLDADOS HISTÓRICOS EN UN PANEL DE ARTE RUPESTRE, PUNO, PERÚ: LOS CAUDILLOS DEL SIGLO XIX Y EL COMENTARIO POLÍTICO ANDINO
}

\author{
HISTORIC SOLDIERS IN ROCK ART FROM PUNO, PERU: \\ NINETEENTH-CENTURY CAUDILLOS AND NATIVE \\ POLITICAL COMMENTARY
}

\begin{abstract}
Elizabeth Arkush ${ }^{1}$
La historiografía de la época colonial tardía y republicana temprana en los Andes ha sido dominada por las voces y las preocupaciones de los criollos letrados. Así, los registros producidos por los propios pobladores andinos rurales son particularmente informativos, incluidos aquellos en los cuales no se utilizó la escritura. En este artículo se describen las Pinturas de Japuraya, un panel de arte rupestre registrado en 2009 cerca de Tiquillaca, departamento de Puno, Perú. El panel principal representa una fila de soldados, músicos y oficiales cuyos uniformes están inusualmente detallados, ligando la imagen al lapso entre 1821 y 1852 , y muy probablemente entre 1835 y 1842 . Más adelante, ilustraciones adicionales de soldados fueron grabadas en la roca, cerca de la imagen original, y otras partes fueron desfiguradas a propósito. Esta representación permite una nueva perspectiva de cómo las fuerzas militares de los caudillos poderosos fueron percibidas por los ojos indígenas en la sierra sur-central en un tiempo histórico de gran agitación y faccionalismo.
\end{abstract}

Palabras claves: Perú, arte rupestre, soldados, uniformes militares.

The historiography of the late colonial and early republican Andes has traditionally been dominated by the voices and concerns of literate elites of Spanish descent. Hence the records produced by rural Andeans themselves are particularly valuable, including those that did not utilize the written word. This paper describes Pinturas de Japuraya, a rock art painting discovered in 2009 near Tiquillaca in the department of Puno in southern Peru. The main panel portrays a line of marching soldiers, musicians, and officers whose uniforms are unusually detailed, pinning the image to a time frame between 1821 and 1852, and most likely between 1835 and 1842. Later, additional soldiers were scratched into the rock near the original pictograph, and parts of the pictograph were intentionally defaced. This portrayal offers insight into how military forces led by powerful Hispanic warlords were seen through native eyes in the south-central highlands at a historical moment of great turmoil and factionalism.

Key words: Peru, rock art, soldiers, military uniforms.

La historia de la época colonial y republicana temprana en los Andes centrales, de finales del siglo XVIII hasta el siglo XIX, se ha construido a partir de los registros de la clase alta: los españoles y los criollos educados. Las poblaciones rurales, en su mayoría indígenas, emergen de vez en cuando en la historia, más dramáticamente en las rebeliones de la década de 1780, y luego se desvanecen nuevamente en una aparente invisibilidad, resultado de una alfabetización limitada. Sin embargo, recientemente los investigadores han dado algunos pasos para penetrar esta invisibilidad. Méndez $(2005,2009)$ ha propuesto, basándose en documentos históricos, que las comunidades andinas rurales estaban de hecho muy involucradas en las luchas militares de los nuevos estados independientes andinos en el siglo XIX.
Salomon et al. (2011) asociaron un quipu de Rapaz, Perú, a la guerra de independencia en la década de 1820, cuando las fuerzas de liberación pasaron por la región varias veces con el apoyo material de las comunidades locales, apoyo que podría haber sido contabilizado cuidadosamente en dicho quipu. Estas pistas ofrecen una visión valiosa de la participación indígena en la política nacional, en una época en la que los considerados "indios" rara vez utilizaron la escritura en sus propias interacciones (Salomon et al. 2011:374). Recientemente, Martínez (2009), Martínez y Arenas (2009) y Arenas (2011) han propuesto que el arte rupestre poscolombino se puede leer como otro tipo de testimonio indígena, que -al igual que otros sitios sagrados del paisaje rural- podría haber permitido a las comunidades

\footnotetext{
$\overline{1}$ Department of Anthropology, University of Pittsburgh, 3302 WWPH, Pittsburgh, PA 15260 U.S.A. arkush@ pitt.edu
} 
campesinas enunciar ideas y realizar rituales fuera de la mirada de las autoridades hispanas y criollas. Sin embargo, la dificultad de fechar precisamente al arte rupestre, por lo general, limita nuestra comprensión de tales usos.

Este artículo describe las Pinturas de Japuraya, un panel de arte rupestre registrado en 2009 cerca de Tiquillaca, departamento de Puno, Perú. El panel principal representa una fila de soldados, músicos y oficiales. Tales temas son bastante comunes en el arte rupestre de la época colonial tardía y republicana temprana en los Andes sur-centrales. Pero, en este caso, el inusual grado de detalle y el uso de cuatro colores permiten fechar el panel a un lapso bien delimitado. Más adelante, grabados adicionales de soldados fueron hechos en la roca, cerca de la pintura original, y ciertas partes fueron desfiguradas. Esta representación ofrece una ventana para considerar cómo fueron vistos los caudillos criollos por los ojos nativos en la sierra sur-central en un momento histórico de agitación y faccionalismo. En términos más generales, las Pinturas de Japuraya ayudan a explorar la importancia política del arte rupestre histórico andino así como la complejidad de tal discurso.

\section{El Arte Rupestre Colonial y Republicano en los Andes}

El arte rupestre tiene una gran antigüedad en los Andes, desde el período arcaico (Berenguer 2004; Guffroy 1999; Hostnig 2013). Generalmente entendido como una acción ritual efectiva, en la época precolombina el arte rupestre puede haber sido utilizado de diversas maneras para santificar lugares específicos en el paisaje, y ritualmente lograr ciertos objetivos: por ejemplo para conjurar la fertilidad de camélidos, para marcar y ritualizar rutas de caravanas y sitios de interacción e intercambio, para señalar identidades étnicas (quizás en relación con el territorio o con derechos de uso) y para reconocer la presencia de figuras de autoridad (Berenguer 2004; Cabello y Gallardo 2014; Sepúlveda et al. 2005).

Después de la conquista, el arte rupestre siguió siendo utilizado como medio de expresión, sobre todo en los Andes del sur y centro-sur (Arenas 2011; Arenas y Martínez 2009; Hostnig 2004; Martínez 2009:10; Martínez y Arenas 2009; Querejazu 1992a; Strecker y Taboada 2004; Taboada 1992; ver también artículos en Querejazu 1992c). A menudo ocupaba sitios ya marcados por el arte rupestre prehispánico, lo que constituye un enfoque repetido en ciertos lugares en el paisaje durante varios siglos o milenios (Querejazu 1992c). En otros casos, sin embargo, se ubicó en sitios nuevos, aunque con frecuencia en lugares alejados de los asentamientos principales (Hostnig 2004:53; Martínez 2009; p.ej., Strecker y Taboada 2004; Taboada 1992). El arte rupestre post-conquista desarrolló nuevos temas y estilos reflejando la transformación religiosa, social y política que se puso en marcha a partir del siglo XVI. Favoreció temas religiosos, como cruces, iglesias, sacerdotes y danzas; jinetes, especialmente en el sur; las figuras con traje europeo, como sombreros anchos; y soldados con armas europeas, a veces luchando en batalla, todos las cuales podemos atribuir con seguridad a la época post-conquista y que a menudo demuestran una preocupación por la dominación hispánica (Arenas y Martínez 2009; Hostnig 2004; Martínez 2009; Martínez y Arenas 2009; Medinaceli et al. 2003; Ponce Oha 2013; Querejazu 1992a, 1992c; Strecker y Taboada 2004; Taboada 1992). Temas tradicionales, como los camélidos, se realizaron también en la época postconquista, pero no son tan fácilmente reconocibles. Las escenas complejas con múltiples figuras humanas en procesiones, danzas y fiestas, batallas, u otras escenas colectivas, son mucho más comunes en la colonia tardía en adelante, tal vez influenciadas por las pinturas hispánicas de escenas históricas y religiosas (Arenas y Martínez 2009; Hostnig 2004:47; Taboada 1992). En concreto se puede categorizar a las Pinturas de Japuraya dentro de un corpus de pinturas rupestres de soldados y batallas de la colonia tardía y la república temprana en la sierra del centro-sur (Figura 1; Hostnig 2004:49; Medinaceli et al. 2003; Ponce Oha 2013; Querejazu 1992b; Taboada 1992:120; Strecker y Taboada 2004). Estas imágenes típicamente muestran múltiples soldados pequeños y esquemáticos, vistos de perfil, que portan armas y otros objetos. Por ejemplo, Medinaceli et al. (2003; también Strecker y Taboada 2004) describen Waylla Ph'uju (LP072), una pintura rupestre compleja del lado oriental del lago Titicaca entre Carabuco y Escoma, que muestra un enfrentamiento entre dos fuerzas, cada una compuesta de filas de jinetes armados y soldados a pie. Los autores interpretan esta escena como el registro de un encuentro violento entre las fuerzas indígenas y las fuerzas criollas en las rebeliones de 1781-2 o el levantamiento de 1870-1. Del mismo modo, Querejazu (1992b) plantea que las pinturas 

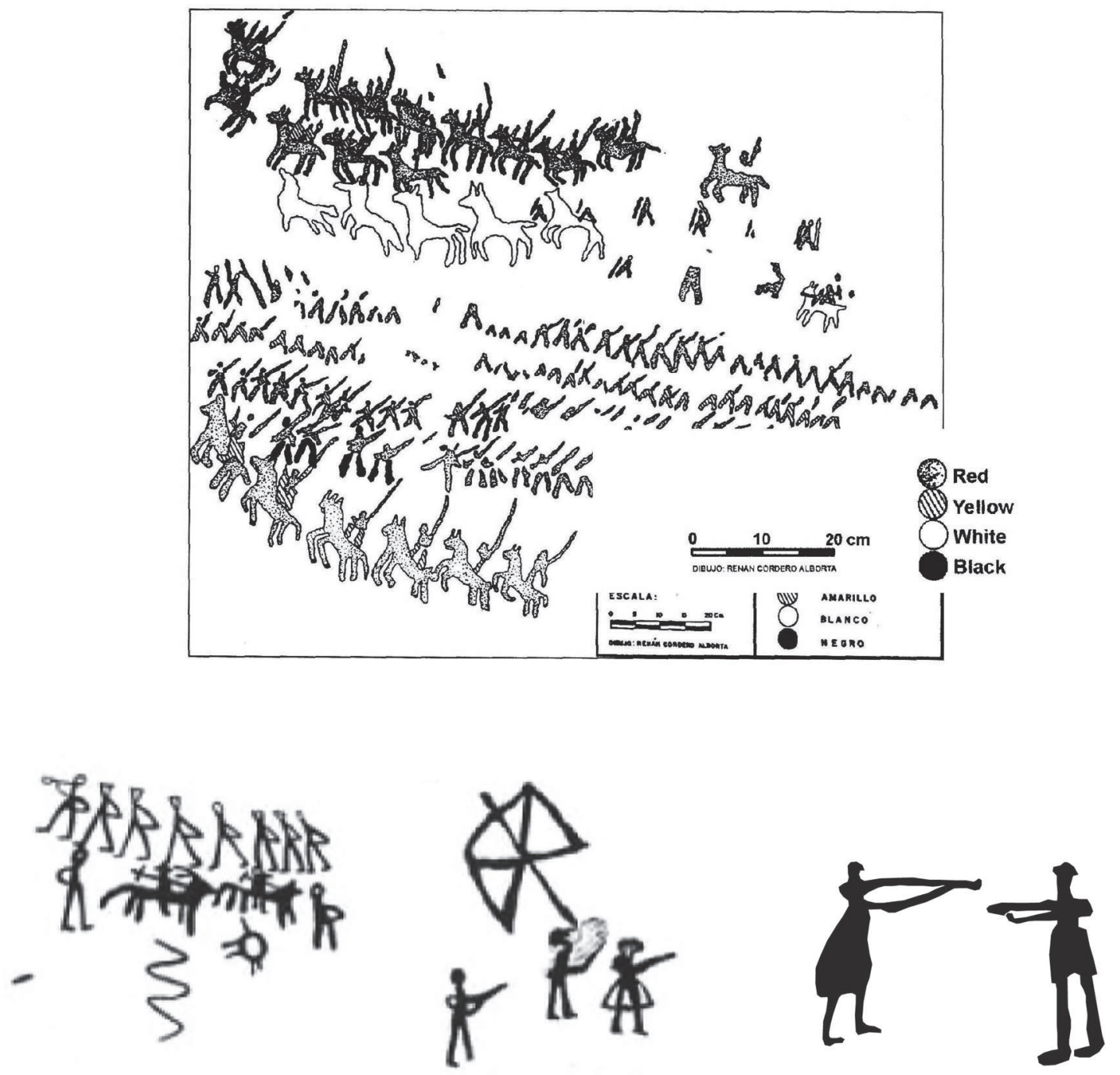

Figura 1. Ejemplos de los soldados, batallas y desfiles militares en el arte rupestre de los Andes centro-sur. Arriba, en el panel de la derecha de Waylla Ph'uju (LP072) de Medinaceli et al. 2003. Debajo, pinturas monocromas (rojo) en Espinar, Cusco, de Hostnig 2004. Examples of soldiers, battles, and military parades in rock art from the south-central Andes. Top, the right panel at Waylla Ph' uju (LP072), from Medinaceli et al. 2003; bottom, monochrome (red) pictographs in Espinar, Cuzco, from Hostnig 2004.

de figuras armadas en el Tunari en Cochabamba, Bolivia pueden recordar los guerrilleros indígenas en la guerra de independencia en 1821-3. Mayormente tales escenas son composiciones relativamente simples y monócromas; Waylla Ph'uju es una excepción, así como lo son las Pinturas de Japuraya.

\section{Las Pinturas de Japuraya (VI-019)}

Fueron registradas en 2009 en una prospección pedestre completa de una zona alrededor de Tiquillaca y Vilque, Puno, Perú. La prospección fue parte de un proyecto más amplio, centrado en un importante asentamiento del período Intermedio Tardío ubicado al sur de Vilque. Posteriormente regresamos en el año 2012 para examinar y documentar la pintura más minuciosamente.

El sitio se ubica en un acantilado largo, orientado en dirección este-oeste en el lado norte de la quebrada del río Japuraya (Figuras 2 y 3 ). Es un lugar protegido y medio escondido, aunque está a solo $2 \mathrm{~km}$ del pequeño pueblo colonial y moderno de Tiquillaca. Aparte de Tiquillaca, el patrón de asentamiento local en el período histórico es de 


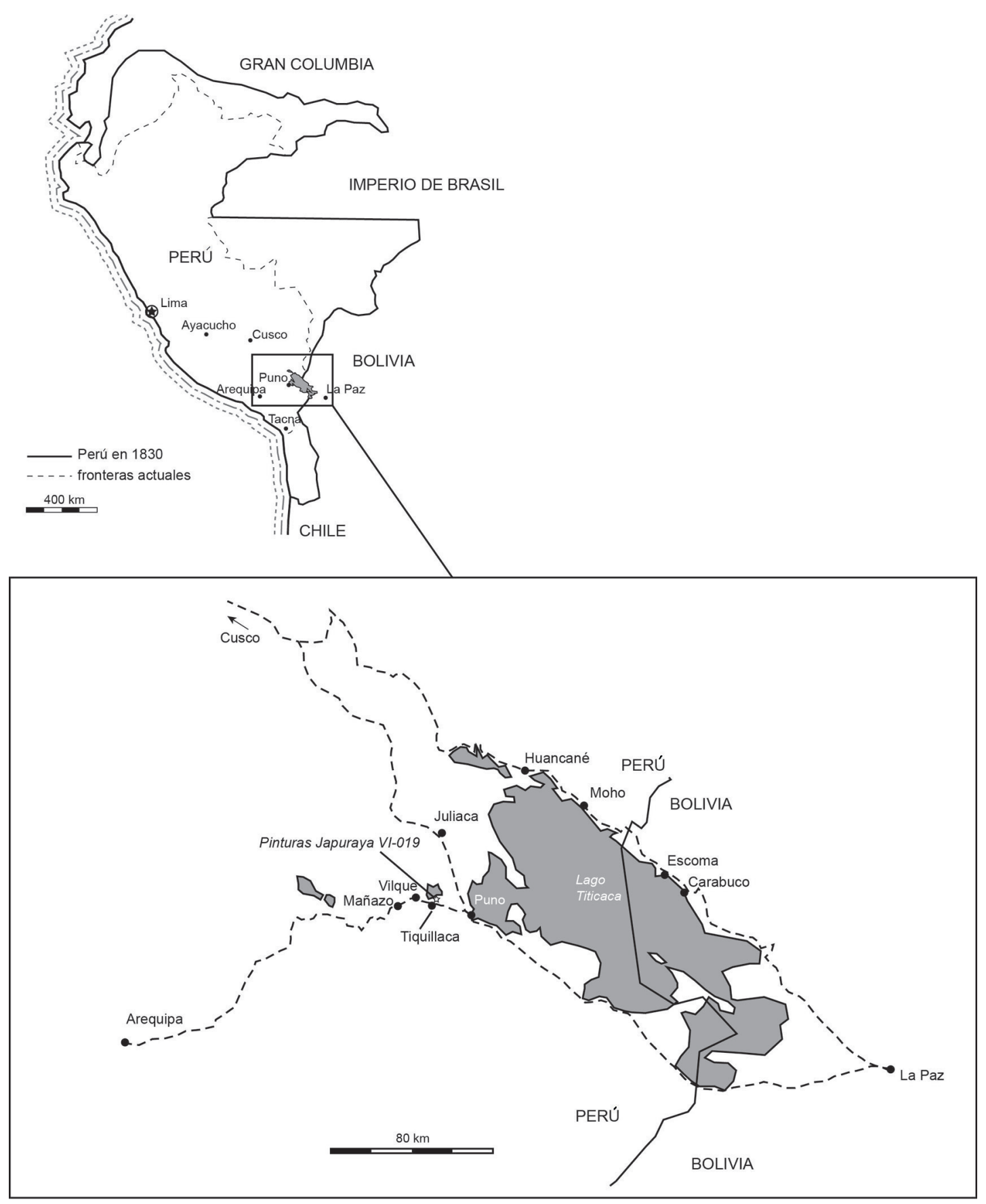

Figura 2. Mapa del Perú ca. 1830, con lugares referenciados en el texto. Map of Peru ca. 1830, with locations in text.

aldeas pequeñas dispersas. Aunque algo aisladas, las Pinturas de Japuraya no estaban lejos de un mundo activo de interacción en la época colonial y republicana (Figura 2). Los pueblos más cercanos, Tiquillaca y Vilque, fueron puestos en la ruta principal conectando Lima y Arequipa a un lado, con Puno al otro, y territorios más lejanos como Bolivia y Argentina. Esta ruta tuvo gran importancia estratégica y comercial hasta la década de 1870 cuando fue eclipsada por el nuevo ferrocarril Puno-Arequipa, 


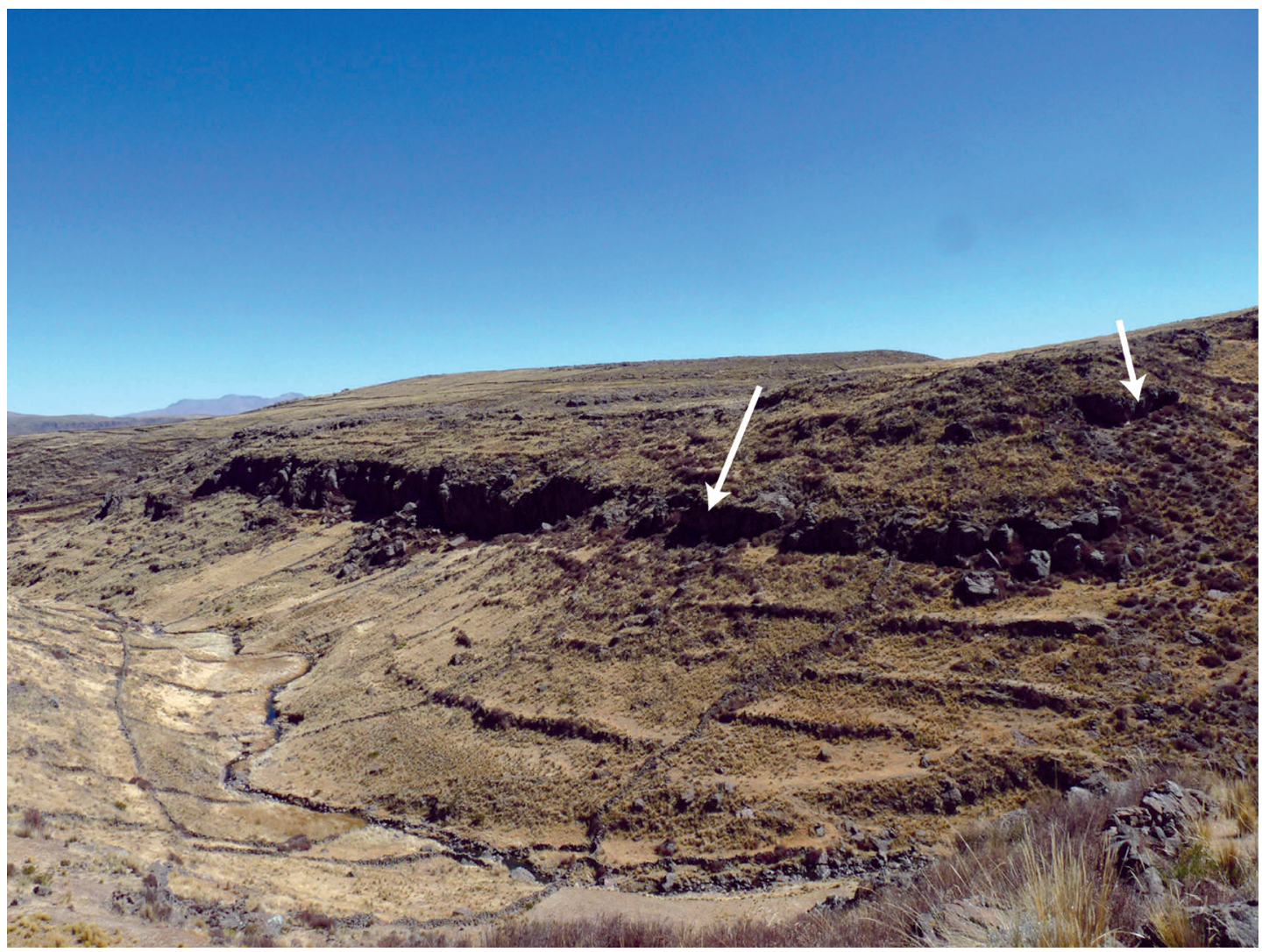

Figura 3. Vista al noroeste hacia el acantilado de Japuraya, indicando la pintura principal (flecha izquierda) y otra pintura de soldados al este (derecha).

View facing northwest towards the cliffside at Japuraya, with the main panel (left arrow) and the second pictograph of soldiers to the east (right arrow).

que cruzó por Juliaca y Cabanillas, sin pasar por Vilque (Meiggs 1871(2):63).

\section{La pintura principal}

La pintura principal se sitúa a 2,7 m por encima del suelo, en la cara de roca arenisca cuya ligera inclinación cóncava y orientación hacia el sur la ha protegido del sol y de la lluvia (Figura 4). Las figuras son pequeñas y siempre están en sombra, ya que no habrían llamado la atención de un observador a más de aproximadamente diez metros de lejos, incluso cuando los colores estaban frescos. La pintura se aprecia mejor desde un muro bajo al lado. Una protuberancia natural encima del panel parece desgastada por el uso y puede haber sido utilizada por los artistas y los espectadores para estabilizarse.

La pintura tiene aproximadamente $1,1 \mathrm{~m}$ de ancho. Muestra soldados caminando y portando armas, vistos de perfil (Figura 5). El centro de la pintura consiste en una fila de diecisiete soldados que llevan sombreros negros, camisas o chaquetas negras, pantalones largos blancos con una barra roja y cinturones rojos (Figura 6). La cara y las manos se muestran en rojo. Sus sombreros negros tienen una franja amarilla en la base, que podría haber sido una banda dorada o, más probablemente, un barboquejo empujado hasta arriba (Julio Luqui Lagleyze, comunicación personal 2013). Los soldados llevan zapatos negros, representados como triángulos. Sobre sus hombros llevan rifles o bayonetas, mostrados como triángulos amarillos estrechos con puntas alargadas. Se ve un elemento amarillo adicional colgando del cinturón atrás de al menos dos soldados, posiblemente un estuche para cartuchos o una cantimplora. Llaman la atención las piernas blancas de las figuras y sus armas exageradamente largas. 


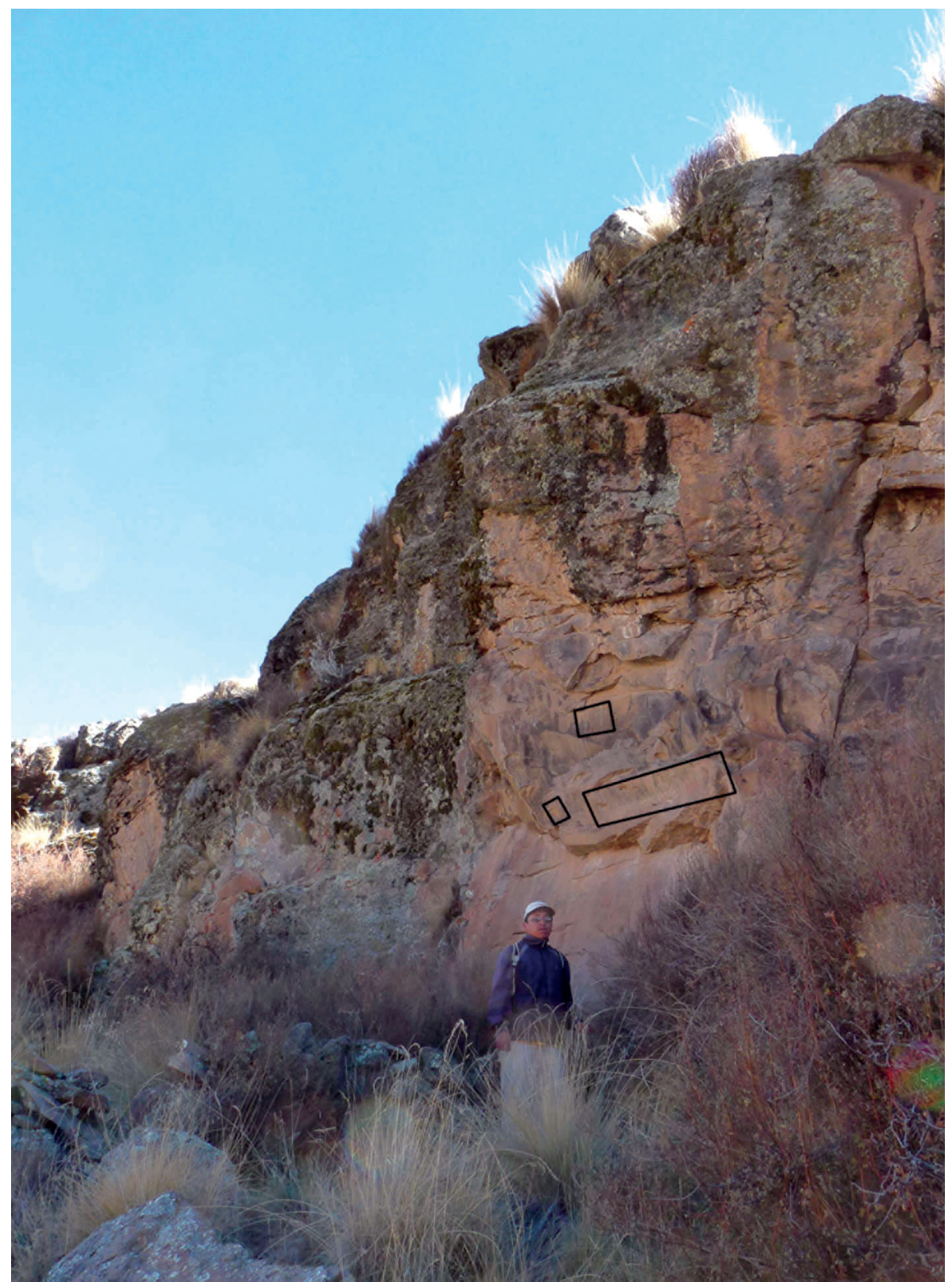

Figura 4: La pintura principal se indica por el rectángulo negro. Los rectángulos pequeños señalan las cruces blancas.

The rock face with the main panel outlined by a black rectangle. Smaller rectangles denote the position of the white painted crosses.

Arriba y a la izquierda se observa un oficial (Figura 7). Está vestido todo de negro con una banda diagonal blanca o bandolera en el pecho. Su saco se extiende hasta la rodilla y parece más largo que el de los soldados. Lleva un sombrero negro -por lo visto un bicornio, o sombrero de dos picos- con una banda amarilla en la base y una mancha roja en la parte superior, quizás un plumero. Otra mancha roja en el cuello o la parte superior del pecho posiblemente representa una medalla. A diferencia de los otros, el oficial levanta una espada y la vaina cuelga detrás.

Otras dos figuras cercanas son difíciles de distinguir porque están dañadas. A la izquierda 


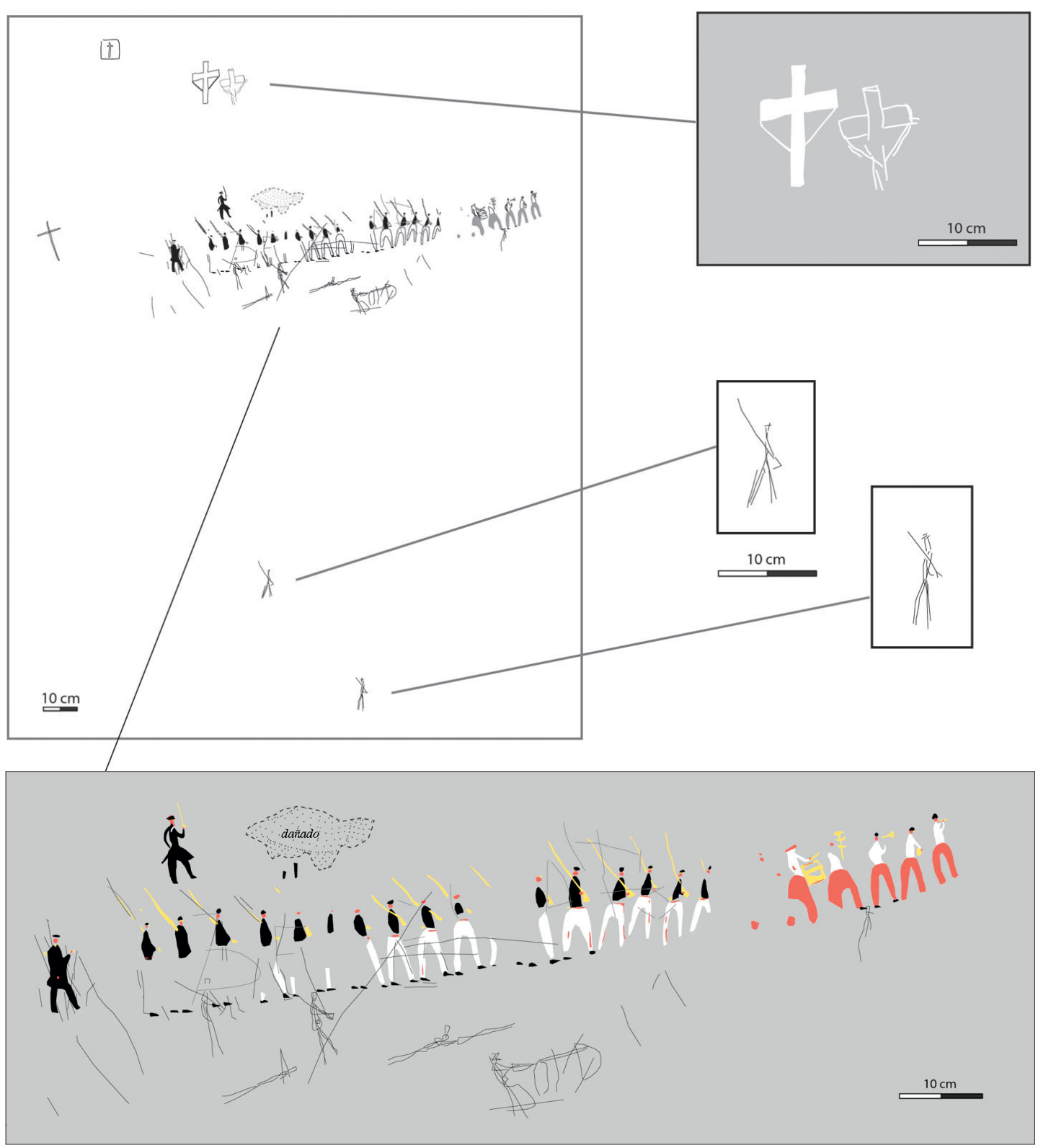

Figura 5. La pintura principal.

The main panel.

de la fila de soldados hay una figura con un uniforme negro, identificándolo como un oficial, que eventualmente fue raspado hasta ser borrado (Figura 8, arriba). Levanta su brazo y agarra un objeto amarillo, demasiado deteriorado para identificar. La otra figura se sitúa por encima de los soldados y parece haber sido destruida con un cincel o pico (Figura 8, abajo). Solo sus piernas son visibles mostrando un pantalón negro; sin embargo, este detalle del uniforme y su posición sugiere que se trata de otro oficial.

A la derecha de la fila, a la cabeza de la marcha, hay un escuadrón de seis músicos vestidos en camisas o chaquetas blancas, pantalones rojos y zapatos negros (Figura 9). Los tres primeros llevan sombreros negros, mientras que el quinto, y quizás el cuarto, lleva un sombrero rojo. Cada uno toca un instrumento pintado en amarillo: de derecha a 

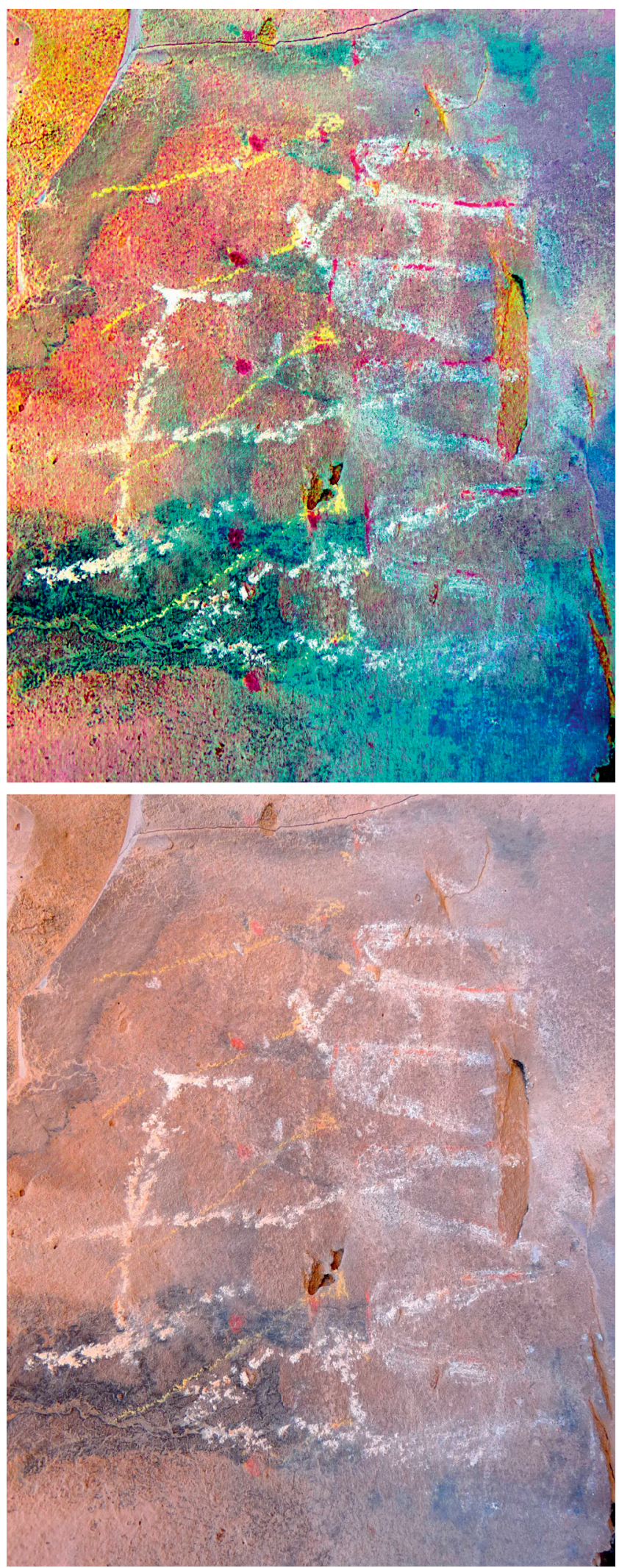

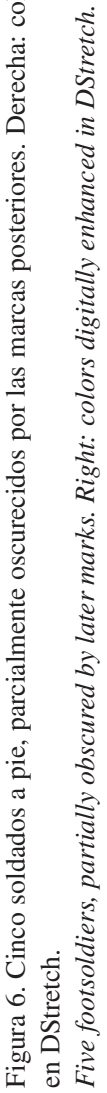



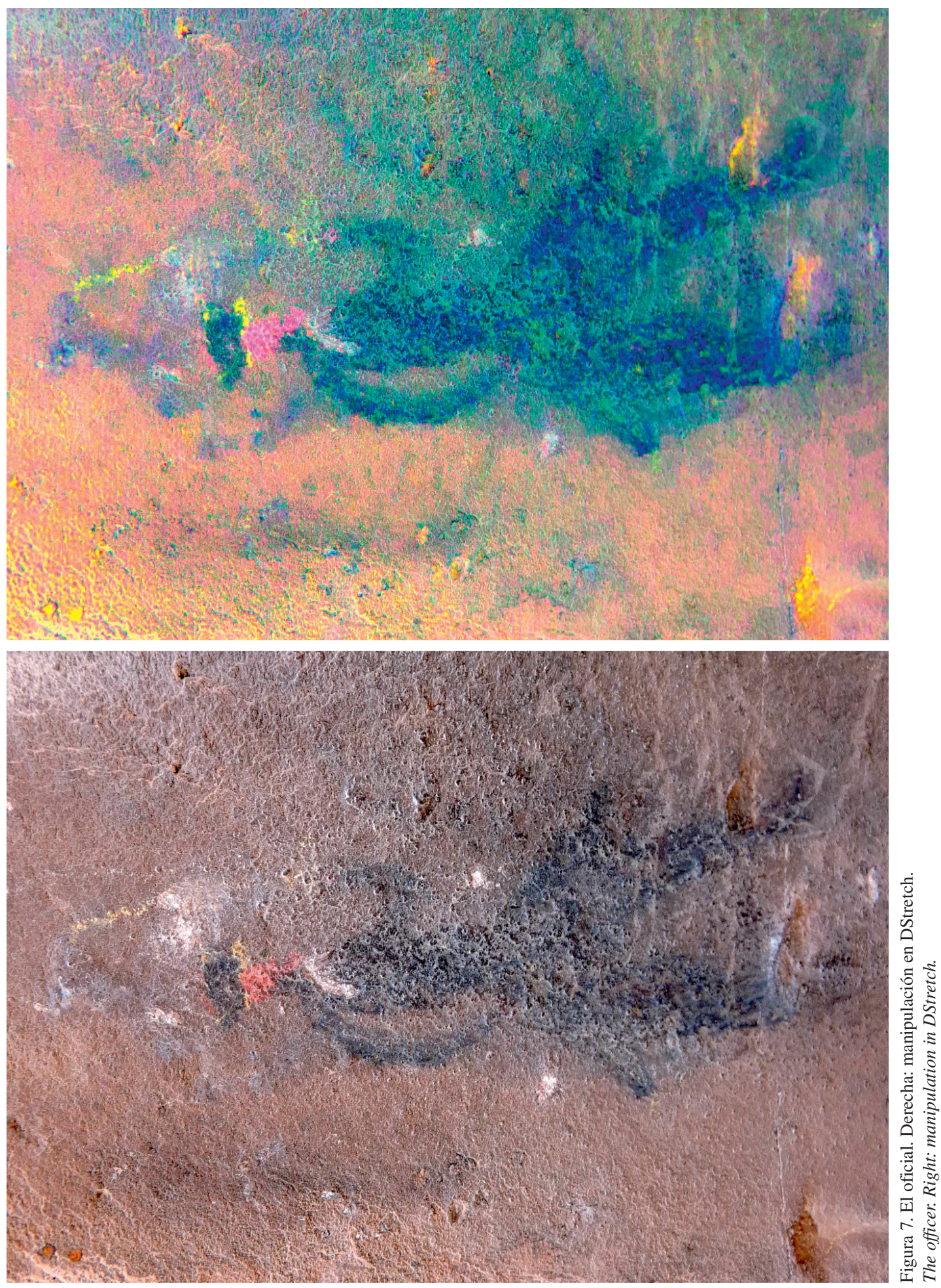

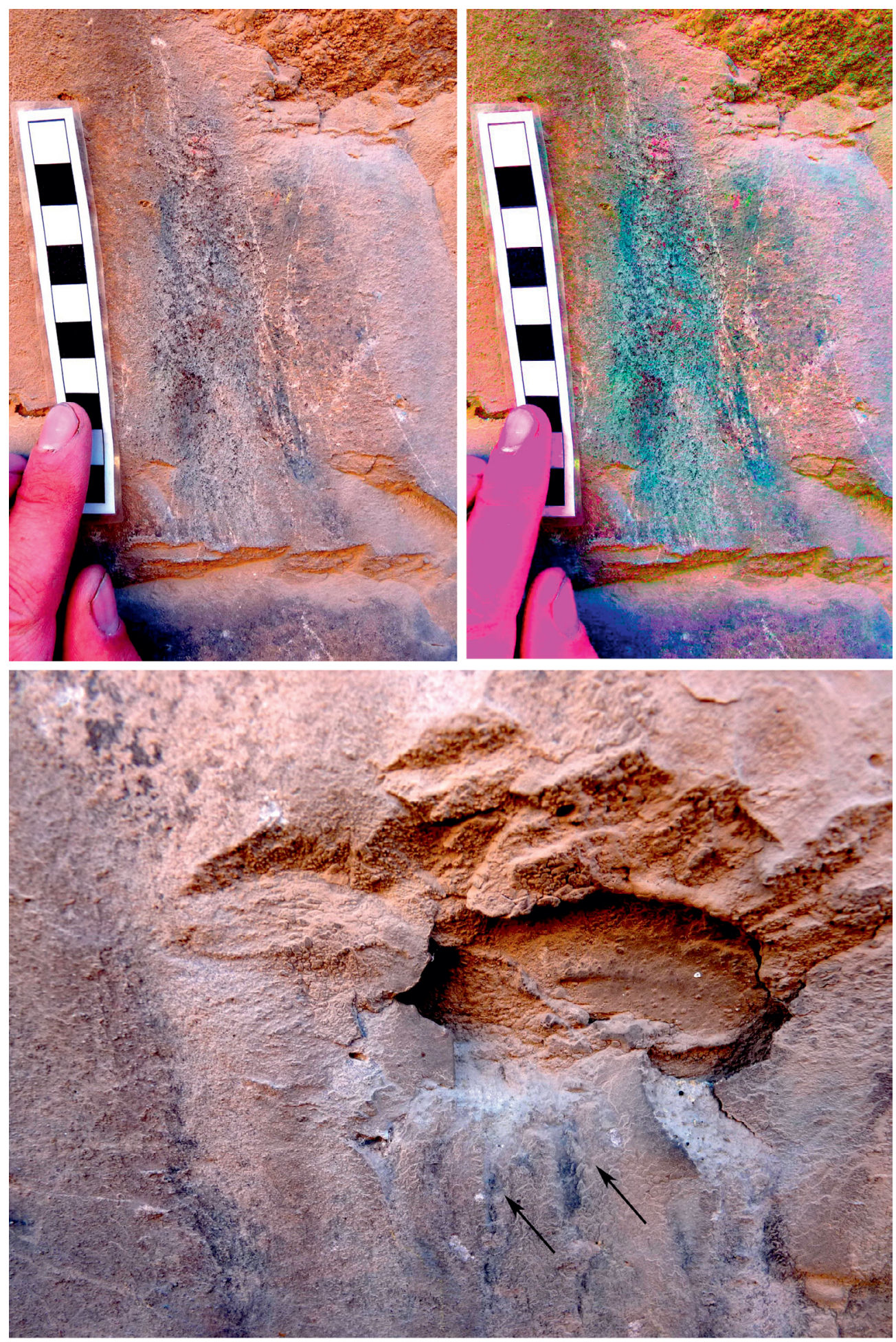

Figura 8. Arriba: Oficial, parcialmente borrado por raspados (derecha, colores aumentados en DStretch). Abajo: otro oficial, por lo visto destruido por cincel o pico. Se ven dos piernas negras debajo del hueco.

Above, officer figure defaced by scraping (right, colors enhanced in DStretch). Below: another officer appears to have been hacked out. Two black legs are visible below the break. 


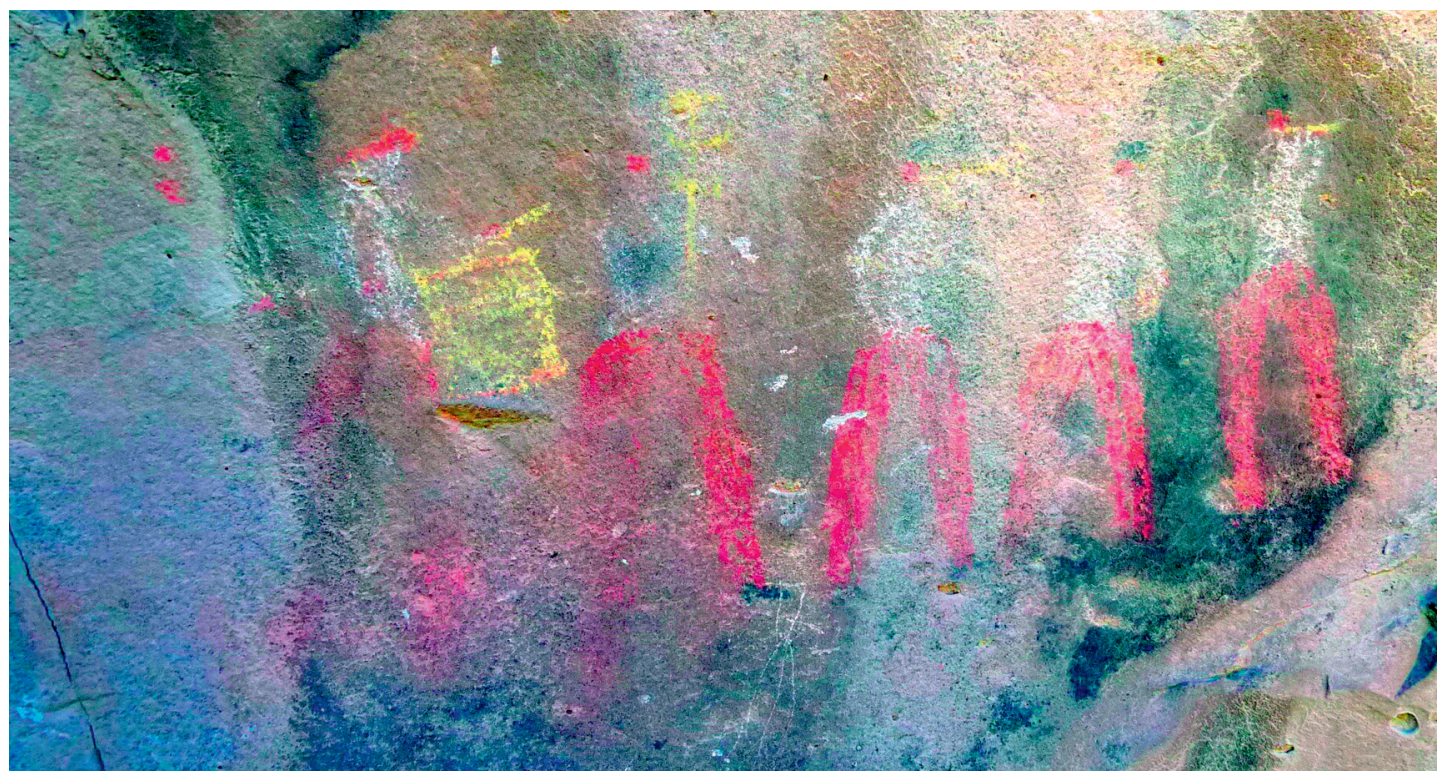

Figura 9: Músicos. Colores aumentados en DStretch.

Musicians. Colors enhanced in DStretch.

izquierda, un pífano, un objeto circular (¿címbalos?), una corneta, una vara alta con ramas horizontales y un tambor. El sexto músico está apenas visible, pero no se pueden distinguir detalles. La vara alta del cuarto músico es, muy probablemente, campanitas chinas (Turkish crescent), un instrumento que fue muy popular en las bandas militares en el siglo XIX tanto en Europa como en las Américas (Blades 2005:265-266, 281; Chenley 1961). Consta de un palo con travesaños de bronce en forma de media luna con campanas (Figura 10). El instrumento se sacudía o se giraba en la marcha.

Aproximadamente $50 \mathrm{~cm}$ encima y a la izquierda del panel, hay dos cruces blancas, casi iguales, excepto que una está pintada de blanco, mientras que la otra solo tiene trazado el contorno (Figura 11). A la izquierda de estas cruces hay una cruz tosca, de color blanco, dentro de un rectángulo blanco y, por debajo, otra cruz blanca tosca. No sabemos si ellas son contemporáneas con la pintura de los soldados; estilísticamente, las cuatro cruces parecen haber sido pintadas por más de una mano.

\section{Modificaciones posteriores}

Tiempo después de la creación de esta pintura, esta fue alterada y, en parte, dañada (Figura 8). Como fue indicado más atrás, el oficial a la izquierda de los soldados fue borrado raspándolo (Figura 8 , arriba) y la parte de la pintura encima de los soldados parece haber sido destruida a propósito, ya que no existe un astillamiento natural similar en la cara de la roca (Figura 8, abajo). La rotura tiene una pátina, pero no se puede determinar su antigüedad. Ambos actos de desfiguración son interesantes porque se dirigen específicamente a los oficiales. Aunque algunos de los soldados fueron oscurecidos posteriormente por grafitos, la intención no parece haber sido de borrarlos.

Varias rayas e incisiones también fueron agregadas a la pintura (Figuras 5 y 12). Algunas rayas replican y hacen hincapié en las bayonetas de la imagen pintada o trazan los pantalones y los zapatos. Además, se trazaron siete soldados alrededor y por debajo de la pintura. Estos tienen sombreros altos, rectangulares y particularmente llamativos, y llevan largas líneas -rifles o bayonetas-. Cuatro soldados caminan o marchan con sus armas al hombro (por ejemplo, Figura 12: izquierda, A, C), pero son retratados como personas aisladas, y no como parte de una marcha o parada coherente. Uno está acostado y parece estar disparando desde una posición cubierta (Figura 12: D), otro está disparando de pie (Figura 12: E). Otro soldado, postrado, es más difícil de interpretar, posiblemente esté muerto (Figura 12: B). Por último, también se 


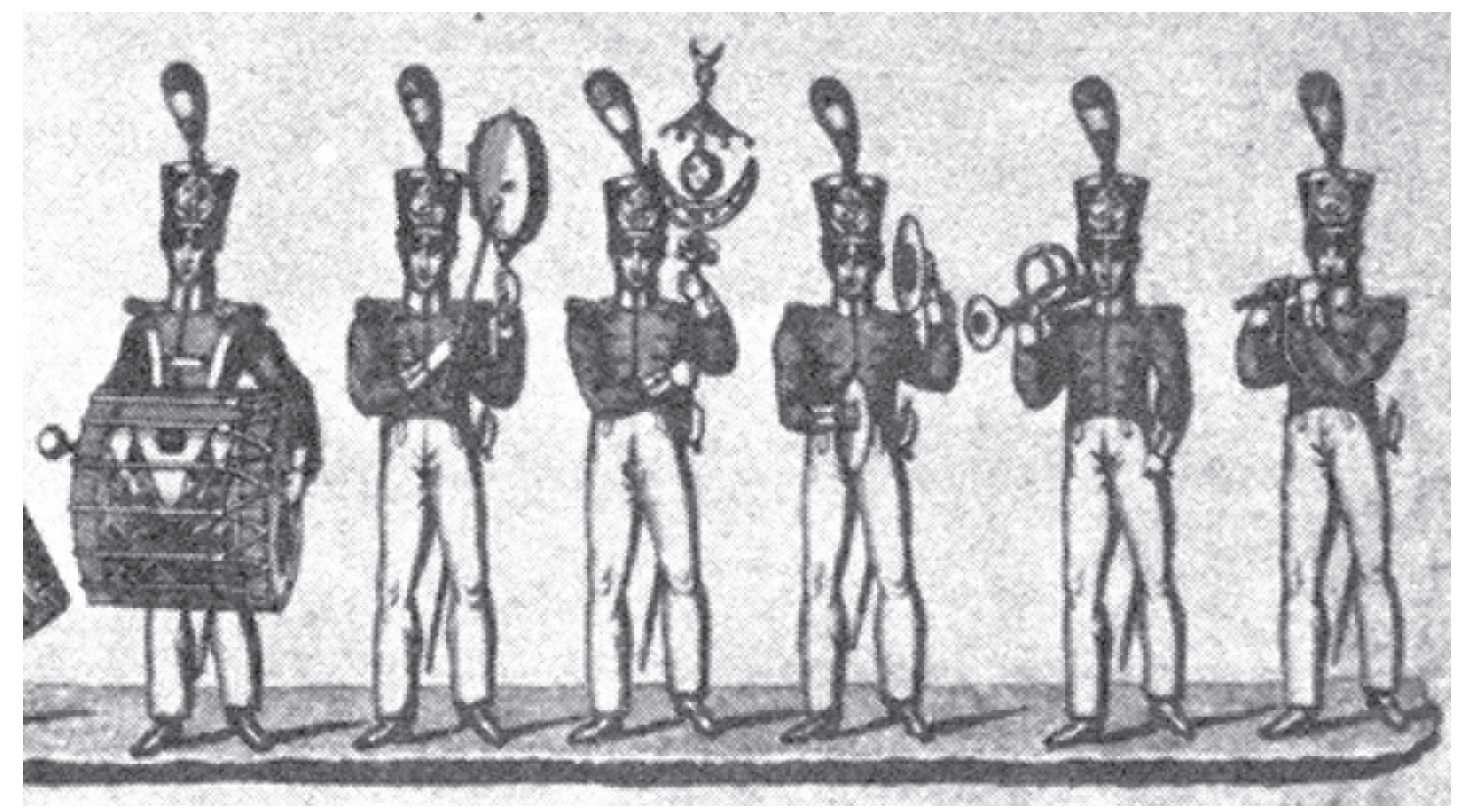

Figura 10. Detalle de "La Musique Royale", una ilustración anónima de una banda militar francesa, 1820. De la derecha a la izquierda, los músicos tocan un pífano, una corneta, címbalos, campanitas chinas, y tambores. Raoul Camus, Military Music of the American Revolution, University of North Carolina Press.

Detail from "La Musique Royale", an anonymous illustration of a French military band, 1820. From right to left, the musicians play a fife, a bugle, cymbals, a Turkish crescent, and drums. Reproduced from Raoul Camus, Military Music of the American Revolution, University of North Carolina Press.

hicieron rayas más anchas, líneas blancas, y algunas letras. Algunas son probablemente recientes pero otras pueden ser más antiguas como la letra "A" y la cruz superpuesta a un grupo de soldados en la Figura 6.

\section{Otras pinturas rupestres cercanas}

Otras pinturas rupestres se encuentran en el largo acantilado de la quebrada. La más estrechamente relacionada se ubica unos 100 metros al noreste y arriba (Figuras 3, 13). Esta muestra cuatro figuras con pantalones rojos, cabezas o sombreros rojos, y camisas o chaquetas blancas. Encima de ellos hay otra figura roja con un sombrero de ala ancha. Aunque sea más tosca, la similitud con la otra imagen sugiere que este también sea una representación de soldados al mando de un oficial. Unas pinturas sencillas en rojo, negro y blanco se encuentran dispersas en la cara del acantilado hacia al oeste (Figura 14). Estas incluyen camélidos, un lagarto, un zorro ( $i$ ?) y seres humanos, incluyendo una figura con un sombrero de ala ancha, disparando un rifle (G). De este modo, es evidente que el acantilado fue utilizado para crear una variedad de imágenes, quizás durante varios siglos.

\section{¿Quiénes eran los soldados?}

¿Quiénes eran, entonces, los soldados? Su traje es claramente de la primera mitad del siglo XIX. Pantalones blancos y chaquetas cortas fueron un uniforme típico de los regimientos de esa época. En ese momento la infantería usaba zapatos (no botas) y llevaba fusiles de chispa, a menudo con bayonetas, mientras que los oficiales podrían usar bicornios, y llevaban espadas decorativas. Con el color negro en los uniformes, el artista probablemente pretende representar el azul oscuro: el negro casi no era utilizado en los uniformes militares de Sudamérica de la época, pero chaquetas de color azul oscuro y pantalón blanco eran los colores tanto de los realistas españoles en las guerras de la independencia, como de los soldados peruanos durante y después de la independencia (Luqui y Manzano 1998; Medina y Mendoza 2005). Pantalones blancos fueron llevados especialmente para la parada (Medina y Mendoza 2005), por lo que la pintura parece 


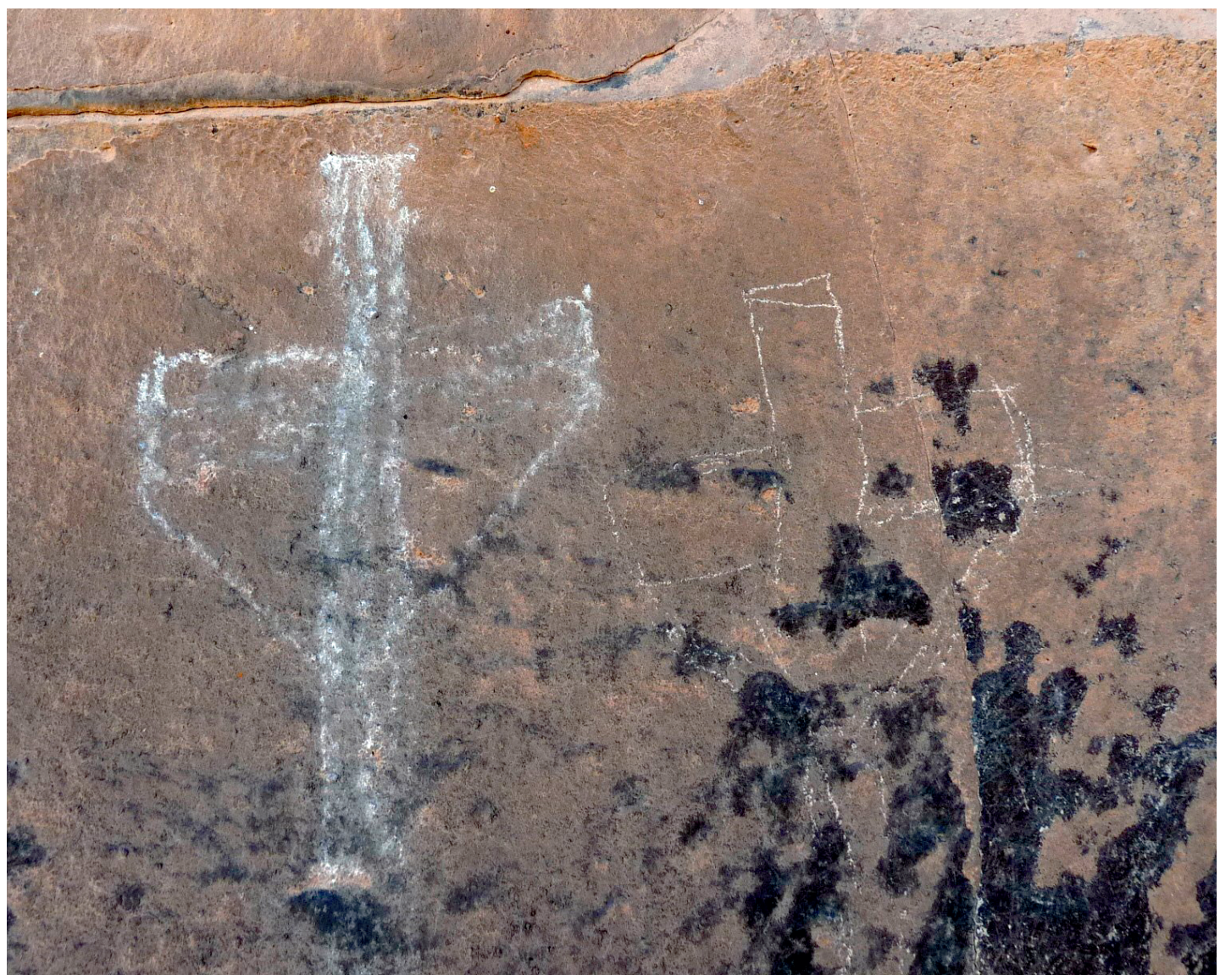

Figura 11. Dos cruces, arriba y a la izquierda de la pintura principal.

Two crosses above and left of the main painting.
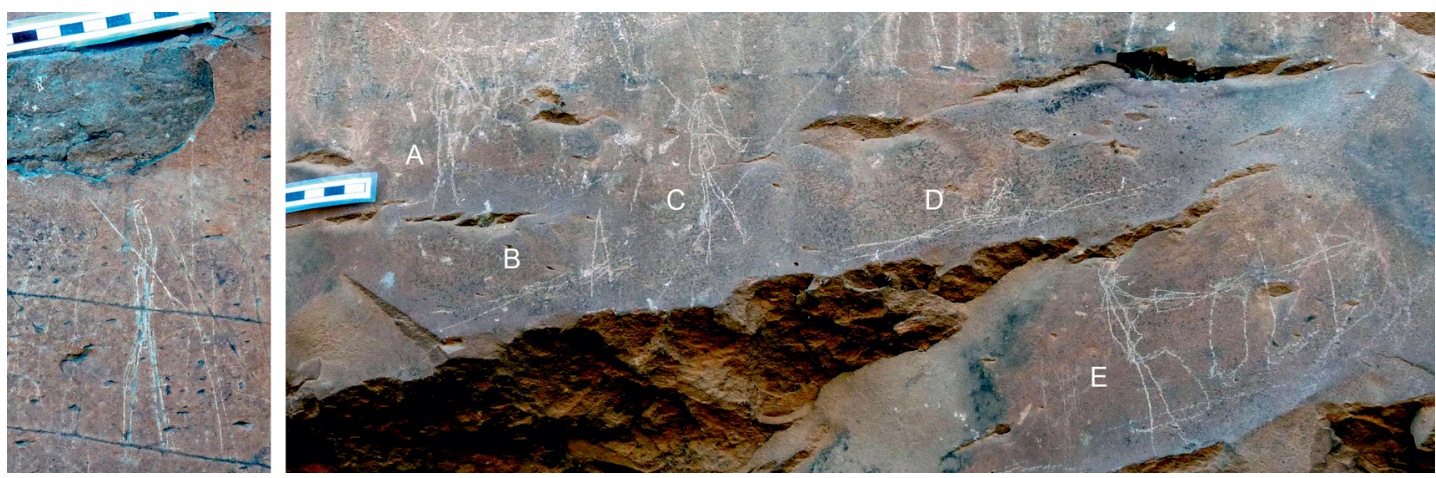

Figura 12. Grabados de soldados, debajo de la pintura. Contraste manipulado en DStretch. Scratched figures of soldiers below the pictograph. Contrast amplified in DStretch.

representar específicamente un desfile, lo que explicaría la presencia de músicos y la variedad de sus instrumentos. Los uniformes en la pintura deben ser de antes de 1852, cuando se determinó que la infantería peruana utilizara pantalones rojos para la parada, y pantalones grises o azul oscuro para la campaña (Oviedo 1865:57).

Pero tres pistas indican una fecha más específica. Primero, los pantalones rojos y chaquetas blancas eran el uniforme de los músicos en el nuevo 

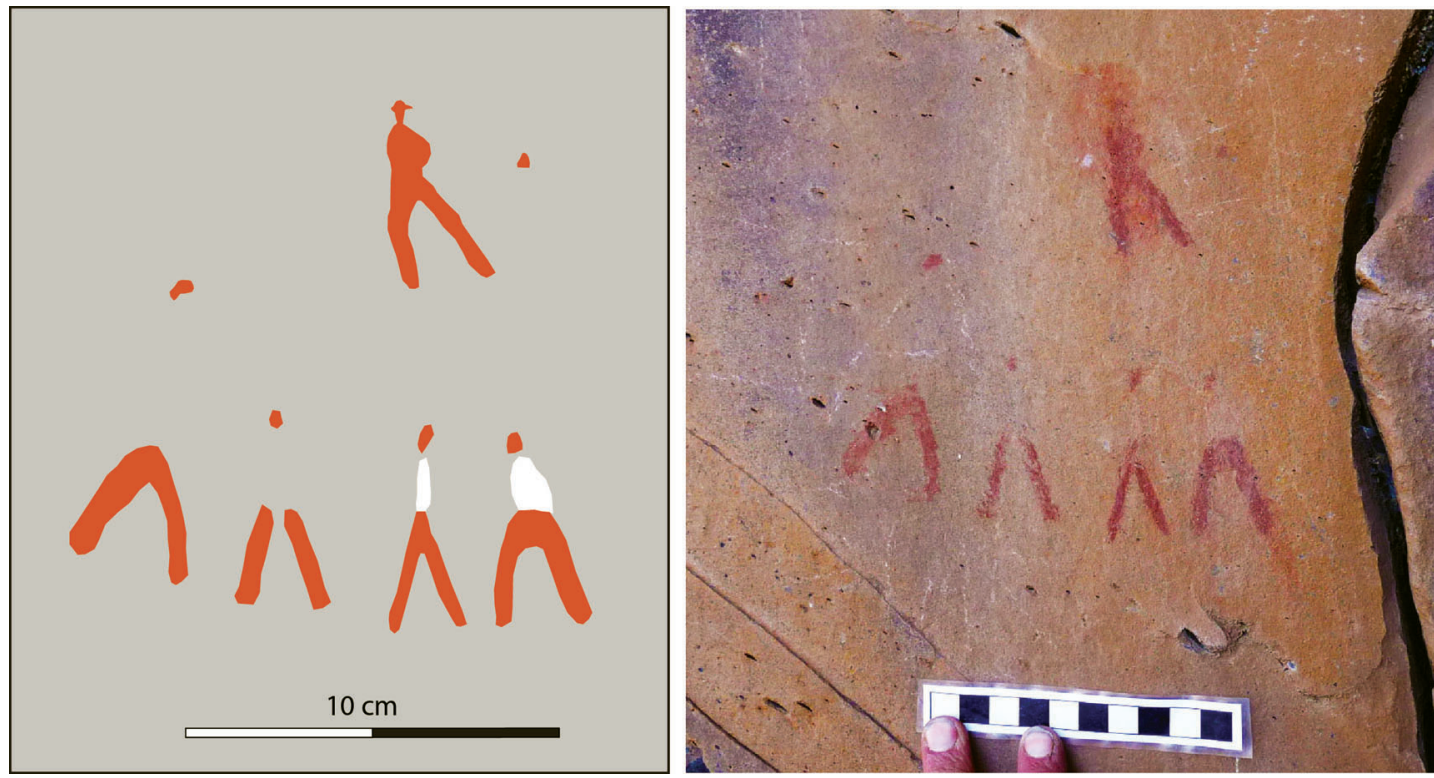

Figura 13. Pintura rupestre de soldados, al este de la pintura principal.

A pictograph of soldiers to the east of the main panel.

ejército peruano después de la independencia en 1824, según cuadros contemporáneos (Julio Luqui Lagleyze, comunicación personal 2013). Los músicos también, de forma exclusiva, llevaban sombreros rojos. En segundo lugar, en solo dos momentos la infantería llevaba barras (rayas) rojas en los pantalones blancos. Para la Legión Peruana de la Guardia, el ejército de liberación de San Martín formado en 1821, los pantalones de parada eran blancos con barra roja, hasta que la independencia en 1825 provocó la emisión de nuevos uniformes (Medina y Mendoza 2005:60-61). Una vez más, bajo el presidente Orbegoso en 1835, los pantalones de bayetón de los uniformes de la infantería eran blancos con una barra roja (Figura 15), hasta que los nuevos uniformes, en 1839, asignaron la barra roja a la caballería y definieron que el azul claro sería para la infantería (Oviedo 1865:48, 53; Lourdes Medina Montoya, comunicación personal 2013). En tercer lugar, el saco largo del oficial parece ser una levita (frog coat), la cual no es mencionada en los reglamentos de los uniformes del Perú antes de 1830 (Oviedo 1865:36, 43, 48) -a partir de ese momento fue permitida para los oficiales, especialmente fuera de la parada, así como el bicornio- (desafortunadamente no es posible distinguir la forma de los sombreros de la infantería pintada ${ }^{1}$ ).
Los soldados incisos tienen mucho menos detalle. Sin embargo, claramente llevan chacós, un sombrero alto en forma de cilindro, a menudo ligeramente más ancho arriba (p.ej., Figura 15), que debe de datar de antes de 1872, cuando otra forma -el quepis- fue introducido para todas las fuerzas peruanas (Medina y Mendoza 2005:108).

En suma, el uniforme de los soldados pintados más probablemente corresponde al período entre 1835 y 1839 , o tal vez poco después, siendo las convulsiones que afectaban al país tan grandes que los uniformes no siguieron muy rigurosamente los nuevos reglamentos, especialmente en las provincias (Lourdes Medina, comunicación personal 2013). Estos soldados, por lo tanto, habrían sido las tropas de la nueva república peruana, en un momento en que los capitanes y soldados iban y venían entre Arequipa, Vilque y Puno en un tumulto desconcertante.

\section{Los caudillos y las guerras civiles}

Las dos décadas inmediatamente después de la independencia del Perú fueron una época de violencia política asombrosa (Basadre 1983). Caudillos ambiciosos compitieron por controlar el país y con los varios golpes de Estado, las luchas civiles y las guerras con otros Estados vecinos había un flujo continuo de tropas armadas 

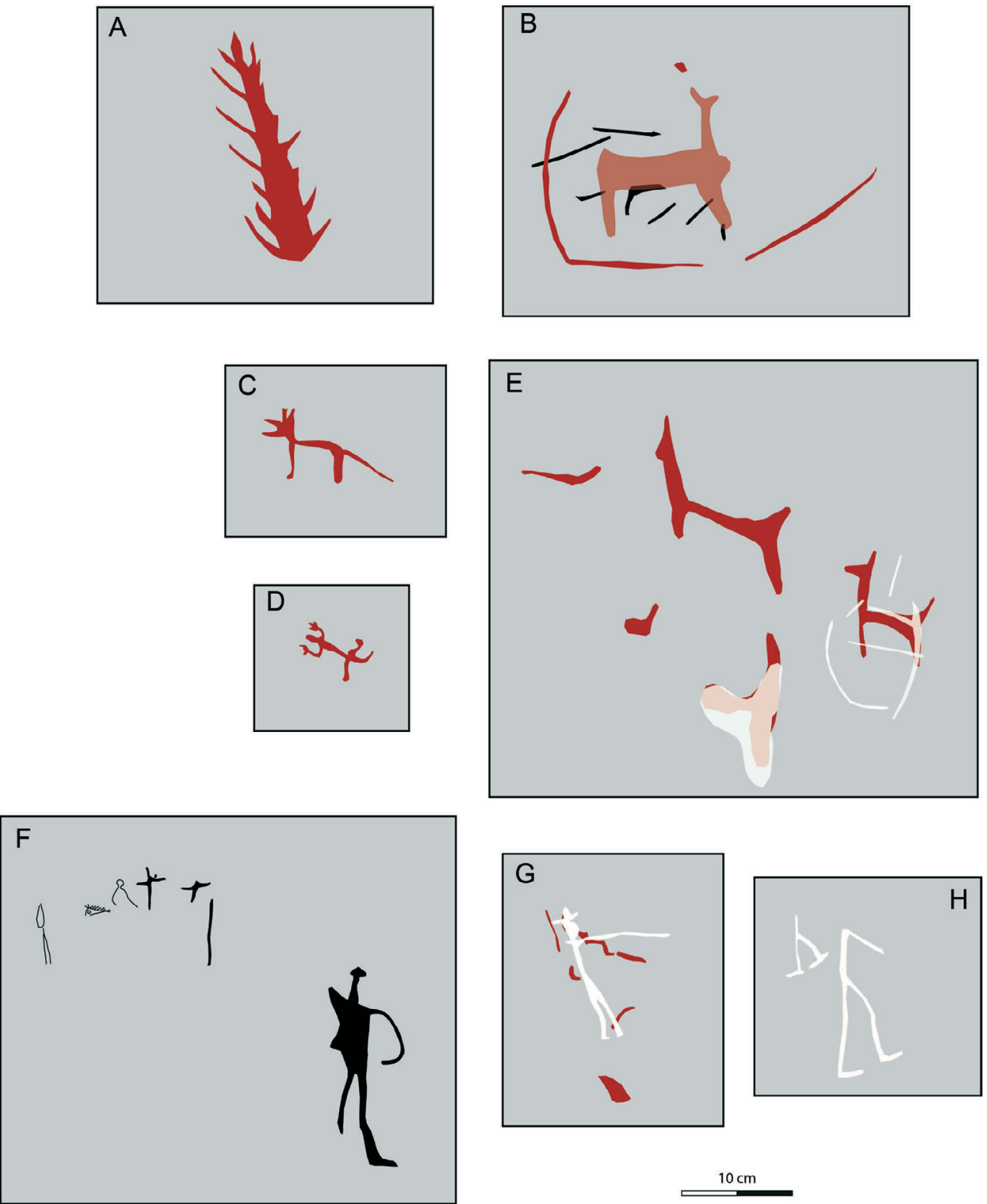

Figura 14. Otras pinturas rupestres en el acantilado, del este al oeste: (A) planta, posiblemente palma sagrada (ver Hostnig 2004:49); (B) camélido con lanzas; (C) zorro?; (D) lagarto; (E) camélidos; (F-H), figuras humanas.

Other pictographs on the cliff face, shown moving east to west away from the main panel (A) Plant, possibly sacred palm frond (see Hostnig 2004:49); (B) camelid with spears; (C) fox?; (D) lizard; (E) camelids; (F-H), human figures.

y guerrillas por las provincias. Como la parte del país más cercana a la frontera boliviana, el altiplano peruano fue especialmente afectado por las guerras de la confederación entre Perú y Bolivia. Varios comandantes hicieron campaña en la zona y miles de soldados se apostaron en varios momentos en Puno, Cusco y Arequipa.
Es lógico suponer que la pintura rupestre se modeló basándose en una parada o desfile que el artista vio en una de las ciudades de la sierra del sur, como Puno o Arequipa. La pompa y la ceremonia aparente y la variedad de instrumentos musicales sugieren una ocasión importante en un centro principal: tal vez la llegada de un gran 


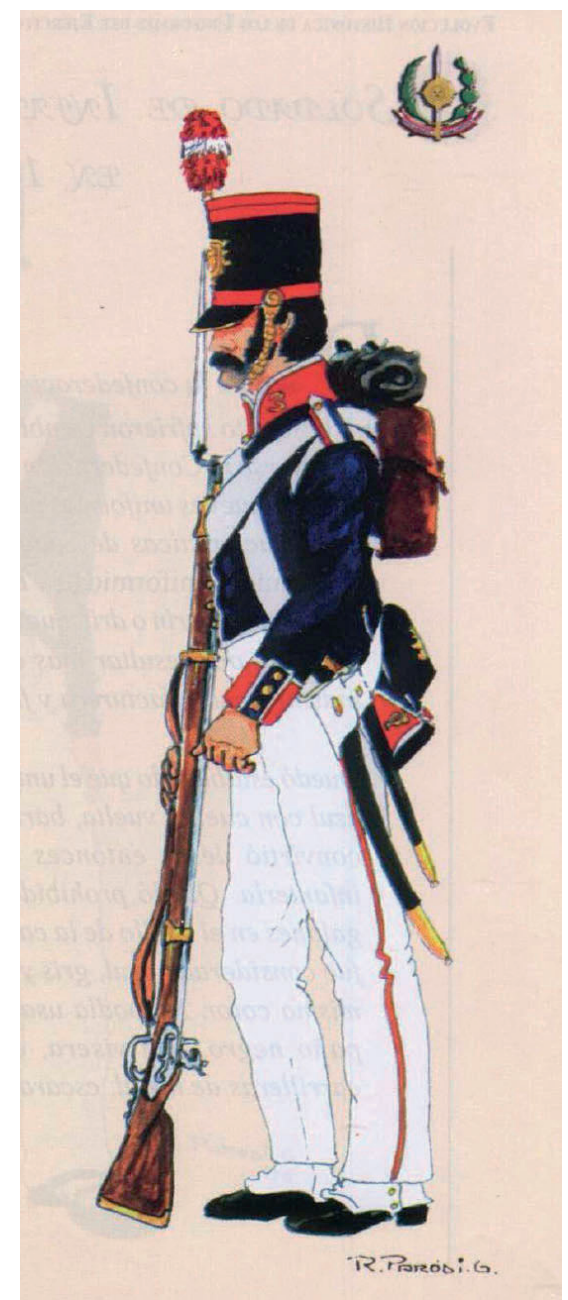

Figura 15. El uniforme de la infantería del Perú de 1835 a 1839. Ilustración de Rodolfo Parodi en Medina y Mendoza (2005:99).

The infantry uniform in Peru's army from 1835 to 1839. Illustration by Rodolfo Parodi in Medina and Mendoza (2005:99).

líder, la ascensión de un nuevo régimen político, una victoria militar o un funeral importante. Hubo varios de esos eventos desde 1835 a principios de 1840. Se resumen brevemente los principales acontecimientos de la época, según Jorge Basadre (1983), con especial atención a las regiones del sur (Figura 2).

Esta fase se inició con la presidencia provisional de Luis José Orbegoso y con el fallido golpe de Estado de Agustín Gamarra en 1834. Gamarra se retiró a su base más fuerte de apoyo popular en Puno, y finalmente aun más allá, a Bolivia. Fue justo antes de la introducción de los nuevos uniformes con la barra roja cuando Orbegoso marchó hacia el sur en su persecución. Pero con el golpe de Felipe Salaverry en Lima, Orbegoso se encontró aislado en Arequipa y, desesperadamente, pidió a Andrés de Santa Cruz, presidente de Bolivia, por ayuda contra Salaverry. Santa Cruz, que tenía la visión de unir las dos repúblicas andinas, accedió a invadir el Perú y Orbegoso ratificó un tratado con él en una carta desde Vilque (muy cerca de las Pinturas de Japuraya). Anteriormente Gamarra había invadido la zona de Puno y marchó hacia al norte, a Cusco, pero esta vez se encontró derrotado por Santa Cruz y fue, finalmente, exiliado. A principios de 1836, las fuerzas de Santa Cruz capturaron a Salaverry cerca de Arequipa. Salaverry fue ejecutado por un pelotón de fusilamiento en Arequipa; sus restos fueron llevados, con gran ceremonia, primero a la catedral, y unos días más tarde al cementerio. Santa Cruz, victorioso, con el asentimiento de Orbegoso, convocó una asamblea de diputados regionales para formar la Confederación Perú-Bolivia, con Santa Cruz como el Supremo Protector.

Después de varias interacciones hostiles, Chile declaró la guerra en diciembre de 1836 con la intención de restaurar el statu quo antes de la formación de la Confederación. El general chileno Manuel Blanco Encalada y sus fuerzas desembarcaron en la costa sur de Perú, marcharon hacia el interior y ocuparon Arequipa. Sin embargo, fueron rodeados por las fuerzas de Santa Cruz y Blanco Encalada no tuvo más remedio que firmar un tratado de paz. Humillado, este vio un gran desfile público de las tropas de Santa Cruz en Arequipa, y luego regresó a Chile. En 1838, una segunda invasión desde Chile fue montada por Agustín Gamarra, que había regresado a Sudamérica y encontró el apoyo de los emigrados peruanos descontentos. En búsqueda de Gamarra en la sierra norte, en enero de 1839, Santa Cruz fue derrotado en la batalla de Yungay y exiliado a Ecuador. Este acontecimiento marcó el fin de la Confederación y la ascensión de Gamarra como presidente de Perú. Poco después, en marzo de 1839, Gamarra cambió los uniformes militares, demasiado estrechamente asociados con Orbegoso y Santa Cruz, así que la infantería ya no llevaba la barra roja en el pantalón (Oviedo 1865:53), sin embargo, este cambio posiblemente no fue implementado inmediatamente en las provincias.

Siguieron levantamientos en varias partes del país, incluso Cusco, Puno y, más significativamente, Arequipa (dirigida por Manuel Vivanco), que fueron 
derrotados por los oficiales de Gamarra. Gamarra pronto decidió invadir Bolivia -débil y anárquicacon el fin de anexarla bajo el control peruano y reinar sobre todos los Andes centrales (en esta campaña, sus fuerzas pasaron por el lado este del lago Titicaca, y no cruzaron Puno). Al principio tuvo la ayuda del caudillo joven boliviano José Baillivián. Gamarra entró en Bolivia y ocupó La Paz, pero las relaciones con Baillivián se deterioraron y la región fue intensamente hostil a los peruanos. En noviembre de 1841 Baillivián y otros bolivianos atacaron a Gamarra en Ingavi, cerca de La Paz y, en esa batalla, Gamarra falleció y la mayoría de sus fuerzas fueron capturadas.

Los generales bolivianos victoriosos, incluido Ballivián, invadieron y ocuparon el sur del Perú, asentándose mayormente en Puno. Pero ellos se encontraron con la feroz resistencia de las guerrillas a lo largo de la cuenca del Titicaca, dirigidas por criollos así como por líderes indígenas, y con la oposición de la Guardia Nacional de Puno al mando del coronel Rudecindo Beltrán. En el invierno de 1842 accedieron a un tratado y las fuerzas bolivianas se retiraron del Perú. Finalmente la sierra sur estaba en paz.

En resumen, entre 1835 y 1842, un elenco cambiante de generales y soldados ocuparon Puno, Arequipa y Vilque. Los soldados pintados podrían haber pertenecido al batallón de Orbegoso en 18356, Salaverry en 1835-6, Gamarra en 1835 o 1840, Santa Cruz en $1835-1837^{2}$, Castilla o Vivanco en 1840, o, posiblemente, la Guardia bajo Beltrán en 1841-1842. Hubo varias ocasiones para paradas militares. Por ejemplo, la ejecución de Salaverry y la humillación de Blanco Encalada a manos de Santa Cruz fueron ambos marcados por desfiles y ceremonias en Arequipa. La formación de la Confederación de Santa Cruz, la ascensión de Gamarra y la muerte de Gamarra podrían haber sido motivo de ceremonias públicas en Puno, Arequipa y otras capitales provinciales. Es posible también que el desfile en la pintura solo marcara una fiesta religiosa, aunque la ausencia de figuras religiosas, evidentes en muchos otros paneles históricos de arte rupestre, hace que sea menos probable.

\section{¿Quién fue el artista?}

Es probable que el artista hubiera sido considerado "indio" en las categorías de la época. La pintura se ubica en un lugar ocupado por otro arte rupestre y está en consonancia con un corpus más amplio del arte rupestre colonial o republicano del centro-sur andino que retrata el movimiento y la procesión, en el que una serie de figuras (soldados, peregrinos, bailarines, jinetes) anda horizontalmente. Generalmente, se considera que estas imágenes fueron producidas por la población local más o menos "indígena" (ver p.ej., Strecker y Taboada 2004). Las caras y las manos rojas de los soldados y oficiales infringen las normas europeas de representación, en las que (teniendo en cuenta los colores disponibles) se esperaría blanco o amarillo. También lo hace el énfasis en las piernas o pantalones, retratados como una gran "U" invertida, a pesar de que está en consonancia con otro arte rupestre andino colonial y republicano (Hostnig 2004; Medinaceli et al. 2003; Taboada 1992). Las Pinturas de Japuraya especialmente se asemeja a las de Waylla Ph'uju, en la margen noreste del lago Titicaca (Medinaceli et al. 2003), en la escala de las figuras, las piernas acentuadas, la paleta de colores y el uso cuidadoso de color para distinguir los uniformes. El artista era probablemente analfabeto: no hay escritura en la pintura original, a pesar de que tuvo cuidado en presentar detalles de los uniformes y el equipo, y probablemente quiso retratar a individuos específicos como los oficiales. Así, las Pinturas de Japuraya son probablemente la representación, por manos andinas, de las fuerzas armadas criollas, mediante el idioma tradicional andino del arte rupestre.

Pero no hay que trazar una clara línea divisoria entre la etnicidad del artista y la de los soldados. De hecho, los soldados indígenas participaron y fueron reclutados para el combate durante el siglo XIX, formando parte de los ejércitos realistas y patriotas en las guerras de independencia (Luqui y Manzano 1998:86-88). Los documentos tempranos de la época republicana dejan en claro que el reclutamiento forzado de la clase baja era una práctica común (ver p.ej., Oviedo 1865:118). Además, las fuerzas guerrilleras indígenas, al mando de sus propios líderes, a menudo lucharon junto con las tropas regulares. A partir de las guerras de independencia, y durante todo el siglo XIX, las guerrillas, o montoneras, jugaron un papel crucial en numerosas campañas, como la resistencia en Puno contra las fuerzas bolivianas en 1841-2 (también Méndez 2009:577-578). Las acciones de las guerrillas constituyen un contexto importante para comprender el arte rupestre del 
siglo: demuestran que las comunidades campesinas andinas participaron activamente en las rivalidades de los caudillos criollos, quienes, efectivamente, dependían en gran medida del apoyo rural, tanto de hombres como de suministros (Méndez 2009). En este contexto, aunque no sabemos si el artista tenía ninguna conexión especial con los soldados o comandantes, parece claro que la representación de las fuerzas armadas debe haber tenido significados políticos, y podría constituir una forma de la acción política intencional.

\section{Hacia la Interpretación del Arte Rupestre como Práctica Política}

Ir más allá de la caracterización de Querejazu (1992a) del arte rupestre andino histórico como "narrativo", reconociéndolo como político (Martínez y Arenas 2009), nos lleva a contemplar cómo las comunidades andinas en esta región confrontaban los acontecimientos contemporáneos de la colonia y la republica temprana, cómo pensaban acerca del proyecto de grabar y hacer comentarios sobre su entorno político (Molinie 1997). Podemos explorar al menos tres maneras distintas de interpretar el arte rupestre post-conquista como una práctica política, que no son mutuamente excluyentes: (1) una crítica oculta o hidden transcript (Scott 1990), quizás una forma de resistencia; (2) una conmemoración, o práctica de la memoria social; (3) y un instrumento ritual.

En primer lugar tenemos la propuesta de Martínez y Arenas (Arenas 2011, Martínez 2009, Martínez y Arenas 2009) de que el arte rupestre fue utilizado como una especie de comentario o crítica indígena, expresando temas y mensajes sobre el poder y la dominación hispana que están totalmente ausentes en el corpus del arte indígena post-conquista más visible para las autoridades, como los qeros (en el mismo sentido, una ventaja de los quipus después de la conquista era su impenetrabilidad para los españoles; Salomon 2004:113). Esta interpretación corresponde precisamente al concepto de James Scott (1990) del hidden transcript: el discurso político que se produce dentro de las comunidades subalternas, en quejas y susurros resentidos, un discurso casi invisible a la historiografía. El arte rupestre en lugares aislados habría sido ideal para la comunicación de mensajes de resistencia, expresando agendas específicamente nativas, o criticando a los poderes dominantes.
Otra manera de considerar la valía política del arte rupestre histórico es verlo como parte de la conmemoración y elaboración de la historia. Fuera de las tradiciones narrativas de la historiografía, las comunidades andinas de la colonia y la república temprana, en efecto, eligieron representar y recordar los eventos importantes recientes con otros medios de comunicación: el canto y el baile, la representación visual, los rituales, las procesiones, los quipus, etc. (Martínez 2000; Martínez y Arenas 2009; Molinié 1997). Algunos ejemplares del arte rupestre colonial y republicano, como las Pinturas de Japuraya, parecen retratar eventos históricos específicos de forma figurativa (y en este sentido, son muy diferentes de la mayoría del arte rupestre precolombino). Crear, alterar y visitar sitios del arte rupestre pudo constituir prácticas de la "memoria social" andina (Connerton 1989). El arte rupestre puede haber sido particularmente apropiado para tales prácticas por que inscribía en lugares específicos en el paisaje la memoria de los acontecimientos y los tiempos pasados, integrando tales eventos en una cosmovisión espacial coherente (Abercrombie 1998). Estas pruebas visibles y permanentes podrían aún servir como validaciones y relictos tangibles de eventos pasados, al igual que los quipus, las estatuas y bultos, los paquetes de documentos guardados o las rocas naturales que seguían siendo consideradas héroes petrificados (Dean 2010:39; Stanfield-Mazzi 2013).

Por último, el arte rupestre hizo más que narrar, criticar o incrustar la memoria del pasado en el paisaje; tenía significados y potencias sagradas. Su producción y su desfiguración podrían haber logrado objetivos de manera ritual, incluso objetivos políticos. Hay evidencia del uso repetido de sitios de arte rupestre durante toda la época colonial para ofrendar y suplicar el favor de los poderes sagrados (Martínez 2009:20; Martínez y Arenas 2009:133), tanto como en años recientes (p.ej., Medinaceli et al. 2003; Querejazu 1992a:8; Strecker y Taboada 2004). El hecho de que se considerara que el arte rupestre tenía poder espiritual también se evidencia en los actos iconoclastas, en el que el arte rupestre precedente (a menudo precolombino) fuera borrado o cubierto con cruces (Bednarik 1988; Querejazu 1992a, también Hostnig 2004:52; Martínez 2009:2426). Tales actos, realizados o por religiosos o por los andinos conversos, habrían desacralizado la imagen anterior, exorcizándola de todo contenido y poder diabólico. Desde esta perspectiva, el arte rupestre colonial y republicano de soldados podría haber sido 
no solo la documentación de los acontecimientos de la época, sino el intento de intervenir mágicamente en un mundo de encuentros violentos y asimetrías dramáticas de poder.

En el caso de las Pinturas de Japuraya, el punto crítico del que hablamos es de una serie de actos: un comentario pintado sobre los acontecimientos políticos de la época, así como las alteraciones posteriores que constituyen comentarios sobre ese comentario. Aunque no podemos precisar el significado político de las imágenes pintadas y grabadas, es bastante seguro que estos significados cambiaron con el tiempo. La pintura original parece principalmente conmemorativa en su intención: registra un evento particular importante que fue marcado en una ceremonia pública. Ciertamente la procesión en sí era una forma de conmemorar y recrear la historia que era totalmente reconocible y familiar para los andinos y criollos en la época. En términos más generales, la pintura da la impresión -al menos, a los ojos occidentales- de retratar un mundo estructurado de orden y jerarquía. El acto de la procesión implica el progreso ordenado mediante el espacio; los músicos evocan la expresión rítmica del tiempo. El rango social y militar se muestra por medio de la aplicación coherente de uniformes, insignias, equipo (siempre en amarillo) y la secuencia. Mientras que el potencial de la violencia está implícito en las armas, es solo latente. La pintura captura la esencia de la parada: la expresión viva y pública del orden y autoridad, tácitamente apoyada por la fuerza. En la fanfarria de las figuras miniaturas gallardas y en el gesto triunfante del oficial, un orden político es reconocido y conmemorado.

¿Es esta una interpretación válida desde el punto de vista indígena en el siglo XIX? Propongo que lo es. Por ejemplo, la disposición de elementos gráficos es la misma aquí que en la axialidad de "buen gobierno" en la obra de Guamán Poma analizada por Rolena Adorno (1988), con los elementos más "altos" (oficiales, cruces) colocados por encima y a la izquierda. Se podría plantear que Pinturas Japuraya tenga algunas similitudes con pinturas rupestres incas del área sur y centro-sur (siendo más notable el Panel Boman y otras pinturas de la Pukara de la Rinconada; Ruiz y Chorolque 2007) que muestran filas horizontales de figuras o unkus coloridos, a veces llevando armas, varas u otros objetos, en las cuales la autoridad y el rango se transmiten mediante el vestido prestigioso, y el orden social, por la repetición de grupos de figuras similares (Ruiz y Chorolque 2007:147-154; véase también Berenguer 2013). Pero, de hecho, buscar un precedente específicamente "andino" es suponer que la población rural de principios del siglo XIX estuvo aislada de un mundo de imágenes hispanas y/o que se mantuvo ignorante de sus significados. Por el contrario, el lenguaje visual de la pintura histórica y religiosa europea impregnaba las iglesias de los andes sur-centrales en la época (Gisbert 1992, 1994), y claramente influyó a Pinturas Japuraya. En los cuadros y murales representando las procesiones y fiestas religiosas (Dean 1999; Gisbert 1994), el espacio de la composición es un microverso social ordenado con varias categorías de personas (funcionarios criollos, kurakas, soldados, etc.) distinguidas por el vestido, la postura y la posición. Si tenemos en cuenta que Pinturas Japuraya participó en una red de imágenes visibles en las iglesias -muchos de ellos hechos por artistas indígenas-entonces transmitía el orden y la autoridad de manera reconocible.

Pero las modificaciones posteriores son harina de otro costal. Algunos rasguños repiten la imagen original con más énfasis, reforzando las líneas de fusiles, pantalones o zapatos; quizás tenían la intención de reconmemorar el acontecimiento al que la pintura original se refería o de reforzar el simbolismo entendido de la imagen. Otros rasguños, aunque replican el tema de los soldados y su orientación hacia la derecha, logran un estilo y un tono notablemente diferente. Los soldados incisos no son parte de un regimiento jerárquico ordenado ni una exposición pública, sino que son combatientes individuales desconectados los unos de los otros. Dos soldados disparan, haciendo una conexión explícita con la lucha, y los soldados incisos que caminan tal vez representan la marcha en lugar del desfile. Sus posiciones heterogéneas y su disposición dispersa, y aun la calidad de su producción artística (líneas rápidas, poco profundas, inexpertas), sugieren un movimiento incoherente, sin disciplina ni líder evidente. La sensación que transmiten estos soldados incisos, entonces, es una de conflicto e individuación.

La desfiguración intencional de al menos uno de los oficiales y, probablemente, dos -dejando el tercero intacto- es un comentario más abiertamente político. Un acto de agresión contra los oficiales, o lo que representaban, se puede interpretar más claramente como una crítica en el discurso oculto. $\mathrm{Si}$ consideramos la pintura original como una 
forma de conmemoración, la desfiguración revisó $\mathrm{y}$, selectivamente, borró la narrativa histórica, expurgando del registro a los oficiales específicos. Vista como "iconoclasta", también puede haberlos despojado de poder espiritual. Si bien su significado exacto es oscuro, la desfiguración, al igual que los soldados incisos, presenta una revisión hacia una representación menos ordenada y coherente de la sociedad, en la que el conflicto se coloca al centro.

\section{Conclusión}

Teniendo como base la tradición precolombina del arte rupestre y la roca esculpida como prácticas política y religiosamente potentes, las transformaciones radicales de la colonia y la república temprana hicieron que el arte rupestre fuera el medio de expresión y conmemoración de un pueblo andino afuera de la "ciudad letrada" (Rama 1984). Siguiendo la sugerencia de Martínez y Arenas de pensar en el arte rupestre como una alternativa al discurso público de la iglesia, del gobierno y de la escritura, entonces este tipo de imagen compleja es una forma subalterna de representar, recordar, comprender y tal vez mágicamente de canalizar o controlar, de alguna manera, a un poder armado dominante y peligroso.

Sin embargo, el caso de las Pinturas de Japuraya y su secuencia de modificaciones, dentro del contexto político de las rivalidades violentas de la república temprana, indican la complejidad de este discurso oculto. Sería equívoco interpretar las Pinturas de Japuraya como una forma de resistencia, porque ese término reduce un mundo sociopolítico complejo y volátil a un modelo diádico de opresores y subalternos. En cambio, lo que este panel de arte rupestre indica mejor es que el "discurso oculto" no fue unánime, y si queremos hablar de "la memoria social andina", esta no fue una visión coherente, sino un proceso multivocal. Este registro dinámico es mejor descrito como una conversación o discusión oculta que involucró la conmemoración original, el énfasis, la adición y la eliminación. Es una secuencia que pareciera estar totalmente de acuerdo con el tumulto político del siglo XIX en la sierra del sur. Tal secuencia refuerza la idea de que los pobladores andinos rurales se involucraron activamente en las luchas entre las facciones de la república temprana. Indica, especialmente, que sus opiniones -incluso las opiniones sobre cómo recordar y entender los acontecimientos de la época- no eran ni unificadas ni inmutables.

Agradecimientos: Mi especial agradecimiento para Julio Luqui Lagleyze y Lourdes Medina Montoya por ayudarme a identificar los uniformes, y para Julio Luqui por la identificación de las campanitas chinas. Doy las gracias a Matthias Strecker por animarme a pensar seriamente en el arte rupestre encontrado en el Proyecto Machu Llaqta. El trabajo de campo fue apoyado por una beca de investigación de la NSF. Humberto Tacca y Daniel Schau ayudaron con el registro del sitio de las Pinturas de Japuraya y ofrecieron observaciones útiles. Doy gracias a los evaluadores del manuscrito. Una versión preliminar de esta obra fue presentada en el Congreso Internacional de Arte Rupestre, SIARB-IFRAO, La Paz 2012.

\section{Referencias Citadas}

Adorno, R. 1988. Guaman Poma: Writing and Resistance in Colonial Peru. University of Texas Press, Austin.

Arenas, M.A. 2011. Representaciones Rupestres en los Andes Coloniales: Una Mirada desde el Sitio Toro Muerto (Comuna de la Higuera, IV Región de Coquimbo - Chile). Tesis de Licenciatura, Universidad Academia de Humanismo Cristiano, Santiago.

Arenas, M.A. y J.L. Martínez 2009. Construyendo nuevas imágenes sobre los otros en el arte rupestre andino colonial. Revista Chilena de Antropología Visual 13:17-36.

Arkush, E. 2012. Arte rupestre en su entorno social: tres ejemplares de los períodos tardíos cerca de la Laguna Umayo, cuenca oeste del Titicaca. Ponencia presentada en el Congreso Internacional del Arte Rupestre SIARB-IFRAO, La Paz.
Basadre, J. 1983. Historia de la República del Perú 1822-1933. Setenta edición, Editorial Universitaria, Lima.

Bednarik, R.G. $1988 \mathrm{El}$ arte rupestre boliviano visto desde el exterior. Boletín SIARB 2:22-28.

Berenguer, J. 2004. Cinco milenios de arte rupestre en los Andes Atacameños: Imágenes para lo humano, imágenes para lo divino. Boletín del Museo Chileno de Arte Precolombino 9:75-108.

----2013. Unkus ajedrezados en el arte rupestre del sur del Tawantinsuyu: ¿la estrecha camiseta de la nueva servidumbre? En Tierras Altas del Área Centro-Sur Andina entre el 1000 y el 1600 d.C.: TANOA II, editado por M.E. Albeck, M. Ruiz y M.B. Cremonte. Ediunju, Jujuy.

Blades, J. 2005. Percussion Instruments and Their History. The Bold Strummer, Ltd. Westport. 
Cabello, G. y F. Gallardo 2014. Iconos claves del Formativo en Tarapacá (Chile): El arte rupestre de Tamentica y su distribución regional. Chungara Revista de Antropología Chilena 46:11-24.

Chenley, B. 1961. Jingling Johnny: A note on the pavillon chinois. Berlioz Society Bulletin 36:29-30.

Dean, C. 1999. Inka Bodies and the Body of Christ: Corpus Christi in Colonial Cuzco, Peru. Duke University Press, Durham.

Gisbert, T. 1992. La pintura mural andina. Colonial Latin American Review 1:109-145.

----1994. Iconografía y Mitos Indígenas en el Arte. Línea Editorial, Fundación BHN, La Paz.

Guffroy, J. 1999. El arte rupestre del antiguo Perú. IFEA, Lima.

Hostnig, R. 2004. Arte rupestre Postcolombino de la Provincia Espinar, Cusco, Perú. Boletín SIARB 18:40-64.

----2013. Camélidos de grandes dimensiones en pinturas arcaicas del centro y centro-sur del Perú. Rupestreweb, http://www. rupestreweb.info/camelidosarcaico.html

Luqui Lagleyze, J.M. y A. Manzano L. 1998. Los Realistas (1810-1826). Hombres en Uniforme $\mathrm{N}^{\circ}$ 5. Quiron Ediciones, Valladolid.

Martínez, J.L. 2009. Registros andinos al margen de la escritura: El arte rupestre colonial. Boletín del Museo Chileno de Arte Precolombino 14:9-35.

Martínez, J.L. y M.A. Arenas 2009. Problematizaciones en torno al arte rupestre colonial en las áreas Centro Sur y Meridional Andina. En Crónicas sobre la Piedra. Arte Rupestre de las Américas, editado por M. Sepúlveda, L. Briones y J. Chacama R., pp. 129-140. Ediciones Universidad de Tarapacá, Arica.

Medina Montoya, L. y R. Mendoza Policarpio 2005. Evolución Histórica de los Uniformes del Ejército del Perú. Oficina de Información del Ejército del Perú, Lima.

Medinaceli, X., M. Strecker y F. Taboada 2003. Arte rupestre histórico de la región del lago Titicaca. XV Reunión Anual de Etnología: 21, 22, 23 y 24 de noviembre 2001, tomo 1, pp. 99118. MUSEF Editores, La Paz.

Méndez, C. 2005. The Plebeian Republic: The Huanta Rebellion and the Making of the Peruvian State, 1820-1850. Duke University Press, Durham.

----2009. Militares populistas. Ejército, etnicidad y ciudadanía en el Perú. En Repensando la Subalternidad: Miradas Críticas desde / sobre América Latina, editado por P. Sandoval, pp. 561598. Instituto de Estudios Peruanos, Lima.
Meiggs, E. 1871. Los Ferrocarriles del Perú. Colección de Leyes, Decretos, Contratos y demás Documentos Relativos a los Ferrocarriles del Perú. Imprenta del Estado, Lima.

Oviedo, J. (ed.) 1865. Coleccion de leyes, decretos y ordenes publicadas en el Peru desde el año de 1821 hasta 31 de diciembre de 1859. Tomo 14. Ministerio de Guerra y Marina. F. Bailly, Lima.

Ponce Oha, H.E. 2013. Entre el color y el signo. Aproximación a las manifestaciones rupestres de la época colonial en Carabaya. En Rupestreweb, http://www.rupestreweb.info/carabayacolonial.html

Querejazu Lewis, R. 1992a. Introducción. En Arte Rupestre Colonial y Republicano de Bolivia y Países Vecinos, editado por R. Querejazu Lewis, pp. 6-27. SIARB, La Paz.

----1992b. El Tunari - Montaña sagrada. En Arte Rupestre Colonial y Republicano de Bolivia y Países Vecinos, editado por R. Querejazu Lewis, pp. 52-66. SIARB, La Paz.

Querejazu Lewis, R. (ed.) 1992c. Arte Rupestre Colonial y Republicano de Bolivia y Países Vecinos. SIARB, La Paz.

Rama, Á. 1984. La Ciudad Letrada. Ediciones del Norte, Hanover NH.

Ruiz, M.S. y D. Chorolque 2007. Arte Rupestre del Pukara de Rinconada: Una Larga Historia Visual. Centro Regional de Estudios Arqueológicos y Universidad Nacional de Jujuy, Jujuy.

Salomon, F., C.J. Brezine, R. Chapa y V. Falcón Huayta 2011. Khipu from Colony to Republic: The Rapaz Patrimony. En Their Way of Writing: Scripts, Signs, and Pictographies in Pre-Columbian America, editado por E.H. Boone y G. Urton, pp. 353-378. Dumbarton Oaks Research Library and Collection, Washington D.C.

Scott, J.C. 1990. Domination and the Arts of Resistance: Hidden Transcripts. Yale University Press, New Haven.

Sepúlveda R., M.A., Á. Romero Guevara y L. Briones 2005. Tráfico de caravanas, arte rupestre y ritualidad en la Quebrada de Suca (extremo norte de Chile). Chungara Revista de Antropología Chilena 37:225-243.

Stanfield-Mazzi, M. 2013. Object and Apparition: Envisioning the Christian Divine in the Colonial Andes. University of Arizona Press, Tucson.

Strecker, M. y F. Taboada 2004. "Aymara” rock art of Lake Titicaca. Rock Art Research 21:111-125.

Taboada, F. 1992. El arte rupestre indígena de Chirapaca, Depto. de La Paz, Bolivia. En Arte Rupestre Colonial y Republicano de Bolivia y Paises Vecinos, editado por R. Querejazu Lewis, pp. 111-169. SIARB, La Paz.

\section{Notas}

1 En 1816 el chacó fue introducido para todas las fuerzas de España en las Américas, en sustitución de los bicornios. Los bicornios siguen siendo usados solo por los oficiales. Se nota que algunos paneles publicados de arte rupestre muestran los sombreros de manera suficientemente detallada como para utilizar este marcador cronológico, p.ej., bicornios en las figuras del combate en Taboada (1992:44, 46, 47) (también Martínez y Arenas 2009:134).

2 En 1835-6, los propios músicos de Santa Cruz habrían llevado los colores bolivianos, pero es posible que una banda militar de peruanos pudo haber tocado en una ocasión importante. 
